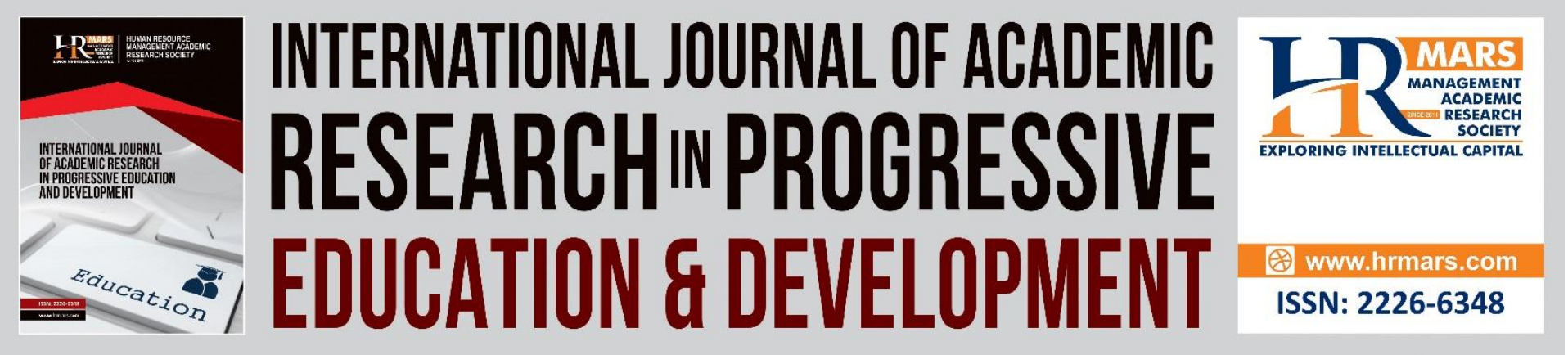

\title{
The Development and Evaluation of Digital Wakelet Module to Improve Information Searching and Use Among Lower Secondary School Students
}

\section{Azlini binti Hussin, Aidah binti Abdul Karim}

To Link this Article: http://dx.doi.org/10.6007/IJARPED/v11-i1/10679

DOI:10.6007/IJARPED/v11-i1/10679

Received: 09 November 2021, Revised: 27 November 2021, Accepted: 15 December 2021

Published Online: 06 January 2022

In-Text Citation: (Hussin \& Karim, 2022)

To Cite this Article: Hussin, A. binti, \& Karim, A. binti A. (2022). The Development and Evaluation of Digital Wakelet Module to Improve Information Searching and Use Among Lower Secondary School Students. International Journal of Academic Research in Progressive Education and Development, 11(1), 60-71.

Copyright: (C) 2022 The Author(s)

Published by Human Resource Management Academic Research Society (www.hrmars.com)

This article is published under the Creative Commons Attribution (CC BY 4.0) license. Anyone may reproduce, distribute, translate and create derivative works of this article (for both commercial and non-commercial purposes), subject to full attribution to the original publication and authors. The full terms of this license may be seen at: http://creativecommons.org/licences/by/4.0/legalcode

Vol. 11(1) 2022, Pg. 60 - 71

http://hrmars.com/index.php/pages/detail/IJARPED

JOURNAL HOMEPAGE

Full Terms \& Conditions of access and use can be found at http://hrmars.com/index.php/pages/detail/publication-ethics 


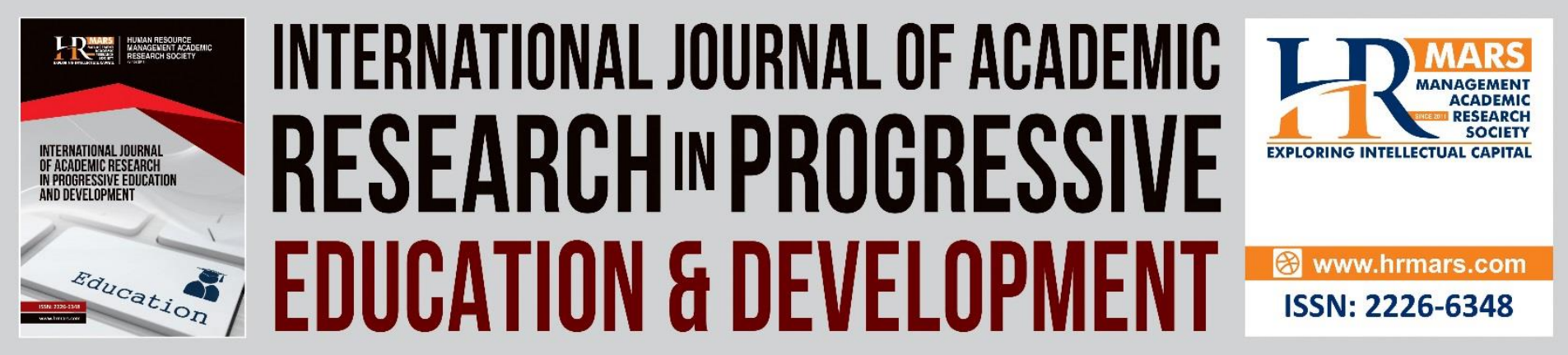

\title{
The Development and Evaluation of Digital Wakelet Module to Improve Information Searching and Use Among Lower Secondary School Students
}

\author{
Azlini binti Hussin, Aidah binti Abdul Karim \\ Faculty of Education Studies, Universiti Kebangsaan Malaysia, 43600 Bangi, Selangor, \\ Malaysia \\ Email:p105632@siswa.ukm.edu.my, eda@ukm.edu.my
}

\begin{abstract}
Although internet offers various classroom learning resources, some students are unable to use the resources due to lack of information searching and use skills. This study aimed to help secondary school students to increase information searching and use in classroom assignments by developing and evaluating digital Wakelet module for lower secondary school students. Using Wakelet application, the students were expected to use appropriate fonts type and style, insert images and videos, and link other features to Wakelet board in completing a digital scrapbook. This study employed action research design and involved 15 form two students in the development of the module and five expert teachers in the evaluation of the module usability. Data was collected using semi-structured interview and document analysis and later analyzed using thematic approach. The study found that the developed module could help students to search information from multiple sources and formats and use the information in the development of digital scrapbook assignment. The study showed that the developed module helps students to search and use information. The study also suggested the use of Wakelet application could faciliate students' application of information search and use among lower primary students. The study suggested that there is a need for lower secondary teachers to master and employ an online application to help students to apply information search and use skills across curriculum.
\end{abstract}

Keywords: Information Searching, Information Use, Secondary Schools, Malaysia, Wakelet

\section{Introduction}

The concept of information literacy was introduced in the middle of 1980 by American Library Association (ALA) (Landoy et al., 2020). ALA (1989) further defined identified information literate individuals as those who can recognize when information is needed and has the ability to find, evaluate, and use it effectively. On a similar note, CILIP Information Literacy Group (2018) stated that information literacy is the ability to think critically and make fair judgments about information that we search and find. Accordingly, information literacy could be perceived a constellation of skills that revolves around search and the use of information 
(Department of Educational Technology, 2002) which defined information literacy as the ability to access and evaluate information to make selection and resolve problems effectively. Jenkins (2006) also stated that information literacy is a set of ability to find, evaluate and use information necessary for any learning process to take place. In education, information literacy facilitates students' learning by helping students to search, evaluate, analyze and use information from multiple sources to construct and communicate personal understanding, and thus making it necessary for students to acquire and apply information literacy across their learning process.

In Malaysia, students' acquisition of information literacy is necessary to support the attainment of the national education policy that stated "Education in Malaysia is an ongoing effort towards further developing the potential of individuals in a holistic and integrated manner, so as to produce individuals who are intellectually, spiritually, emotionally, and physically balanced and harmonious, based on a firm belief in and devotion to God." Moreoever, the development of information literate students would be able to support the Malaysian Education Transformation Plan that highlighted the use of Information and Communication Technology (ICT) in attaining learning outcomes and education goals. Besides, information literate graduates are the key to drive knowledge economy and society that are characterized by a vast majority of the population to have access to ICT and a significant growth in knowledge intensive service sectors such as education, communication and information respectively.

However not all secondary school students are information literate. Murugan et al (2017) found that school students lack the skills of searching and using information. Similarly, Moosavi et. al (2018); Shorfuzzaman \& Alhussein (2017) found that students nowadays use information technology ICT for entertainment and social purpose and not for learning; indicating by their insufficient knowledge and skills in searching and using information respectively.

The problem of information search and use skills among school students would hinder the attainment of ICT curriculum introduced in secondary schools. The goal of the ICT curriculum is to develop students with ICT knowledge, skills, and culture that enable them to solve daily problems and develop positive attitudes and noble values necessary to build caring, dynamic and progressive individuals at individual and community levels. However without sufficient information search and use skills, students would not be able to benefit from ICT in facilitating them to participate and adapt in latest reforms in education system and job market sectors. In particular, the application of technology in education could be seen on the rise with the emergence of various online learning applications such Google Classroom (Hanoum et al., 2019). Google Classroom could increase students' learning interest and attention because there were many interesting online learning applications that can be linked to Google Classroom such as Wakelet, Padlet, Quizizz, Blendspace, Edupuzzle, Kahoot, Plickers and Tinkercad. These online learning application are suitable for teenagers because they provide interesting, interactive and dynamic learning environment. The online learning applications are helpful to solve problems related to time limitation often faced during face to face (f2f) learning environment. This is particularly true during Covid-19 pandemic period in which a drastic increase in the use of online learning was observed (Firmiana et al., 2020).

Therefore, this study aimed to help lower secondary school students to acquire and apply the skills of information searching and use in developing digital scrapbook by developing and evaluating digital Wakelet module. Using the digital Wakelet module, students were expected 
DEVELOPMENT

Vol. 11, No. 1, 2022, E-ISSN: 2226-6348 @ 2022 HRMARS

to search and use information from multiple sources in multiple formats to develop interesting, colourful and meaningful online scrapbooks for their classroom assignments.

\section{Literature Review}

The Australian and New Zealand Information Literacy Framework (Bundy, 2004) defined information use as the process of using information and knowledge about the culture, ethics, economy and issues around us to solve daily information problems. Accordingly, Bundy (2004) stated that information use skills include the ability of of selecting appropriate methods and using effective information retrieval strategies to ensure an effective and efficient information retrieval process and later applying the information to resolve problems of information and knowledge regarding the culture, ethics, economy and other issues around us. Eisenberg and Berkowitz (1987) further stated that information use skills include the ability to read, listen dan browse the sought information and retrieve information again if necessary.

Among indicators of information use skills are the ability to use existing or new information to build new concepts and assimilated the concept into a new undertanding or knowledge (Eisenberg \& Berkowitz, 1987). Meanwhile, Wijetunge and Alahakoon (2005) argued that other indicators of information use skills are the ability to review and use feedback and other assessment subsequent learning activities or assignments or apply the constructed knowledge in a variety of situations and use the knowledge to add value to existing products and portfolio.

According to The Australian and New Zealand Information Literacy Framework (Bundy, 2004), information search skills can be defined as a skills that require individuals to select process of selecting appropriate methods and use effective information retrieval strategies so that the information retrieval process can be done effectively and efficiently. Omar (2005), stated that information search skills are necessary to assist individuals to gather information in order to solve problems or increase their level of understanding and knowledge. According to Eisenberg and Berkowitz (1987), information search skills involve the identification of various information sources activities that identify all sources of information that can be used and later select the best sources of information for a given purpose. Information search skills have several indicators such as searching information resources that match the selected topic, searching information relevant to the selected topic and conducting interviews, field studies or other external research (Wijetunge \& Alahakoon, 2005). Eisenberg and Berkowitz (1987) stated among indicators of information search skills are the ability to identify potential sources of information, formulate search strategies, search for different types/formats of information sources, refine search strategies if necessary, and extract information from sources.

\section{Methodology}

This study employed action research design. Action research is a form of self-reflection inquiry implemented collectively by practitioners to improve their own practices and improve their understanding about those practices as well as the situations where the practices are carried out (Kemmis \& McTaggart, 1988). Similarly, McNiff (1988) stated that action research is an approach to improve the quality of education through changes by encouraging teachers to understand, reflect upon and change their own practices.

This study employed an action research study because the study enabled teachers to improve their teaching practices aims to help students to improve their students' ability to search and 
use information in various formats and sources. This study employed action research design because the design enabled classroom teachers to improve their existing teaching and learning approach through a systematic process of planning, implementation, observation and reflection as a process that was highlighted by (Kember and Gow, 1992).

In particular, the study employed action research model by Kurt Lewin (1946) that stated action research is a recursive circle that consists of four phases; i.e., plan, act, observe, and reflect on the effectiveness of the action that has been done. This study employed the model of research phases are clear, compact and easy to follow.

The study was conducted in a secondary school in a rural area in Malaysia. During the planning and acting phases, 15 form two students and three classroom teachers involved in the identification of the problem to be solved by designing and developing Wakelet module. The selected students do not have ICT skills, while the selected classroom teachers were teachers who often use scrapbook as classroom assignments. Later during the reflection phase, five expert teachers involved in the evaluation of the developed module. The expert teachers have a degree in ICT related program and have taught ICT subjects in secondary schools. Specifically, the expert teachers were required to evaluate the usability of the module learning outcomes, activities, tasks and assessment.

The study employed various research instruments to collect data. During the planning phase, the study used semi-structured interview with 15 students and three classroom teachers in order to understand the issues of information searching and use faced by the students in completing their scrapbook assignments. The study also conducted document analysis on students' previous scrapbooks in order to examine how students searched and used information in their scrapbooks. Data from the planning phase was used to develop Wakelet online module that was intended to assist students to acquire and apply information seacrh and use in completing their scrapbook assignment. Lastly, semi-structured interviews were also conducted during the reflection phase of the study with five teacher experts to evaluate the usability of learning outcomes, activities, tasks and assessment of the developed module.

\section{Findings of the Study}

An early observation on form two students in a secondary school located in a rural area in Malaysia indicated that the students lack the skills of information searching and use in completing their classroom asssignment. For example, it was observed that the students produce uninteresting, shallow and uncreative scrapbooks for their classroom assignments. This is further explained through scrapbooks that have been produced by students in past learning. Findings through the document analysis that conducted on the scrapbook, it was found that there were many shortcomings in its production. Students had produced scrapbooks through the conventional methods and detected many disadvantages such as lack of detailed information, lack of interesting pictures, uncreative, messy writing and also being left behind due to not using a combination of ICT at all. This disadvantages are because of their information search and use skills are not extensive and limited to the resources available around them only.

Besides that, this study also found that form two students faced a problem in searching pictures while completing their scrapbooks. As illustrated in table 1, four out of five form two students interviewed in the study stated that they faced difficulty in searching and using appropriate pictures in their history scrapbooks. Such difficulty might be the reason why two of the interviewed students failed to complete their history scrapbook project, and most of the students did not satisfy with their scrapbook outcome. Moreover most of the students 


\section{DEVELOPMENT}

Vol. 11, No. 1, 2022, E-ISSN: 2226-6348 @ 2022 HRMARS

stated that they did not use interesting and colourful fonts in their scrapbook, indicating that students were unable to develop interesting scrapbook.

TABLE 1: SUMMARY OF STUDENTS' INTERVIEWS

\begin{tabular}{|c|c|c|c|c|c|}
\hline $\begin{array}{l}\text { The questions / } \\
\text { Answer }\end{array}$ & $\begin{array}{c}\text { Student } \\
1\end{array}$ & $\begin{array}{c}\text { Student } \\
2\end{array}$ & $\begin{array}{c}\text { Student } \\
3\end{array}$ & $\begin{array}{c}\text { Student } \\
4\end{array}$ & $\begin{array}{c}\text { Student } \\
5\end{array}$ \\
\hline $\begin{array}{l}\text { 1. Are you } \\
\text { completing } \\
\text { History } \\
\text { scrapbook? }\end{array}$ & Yes & Yes & No & No & Yes \\
\hline $\begin{array}{l}\text { 2. Are you } \\
\text { satisfied with } \\
\text { the production } \\
\text { of the } \\
\text { scrapbook? }\end{array}$ & No & No & $\begin{array}{l}\text { Don't } \\
\text { know }\end{array}$ & No & Yes \\
\hline $\begin{array}{l}\text { 3. Are you } \\
\text { using } \\
\text { interesting and } \\
\text { colourful } \\
\text { fonts? }\end{array}$ & Neutral & No & No & No & Yes \\
\hline $\begin{array}{l}\text { 4. What is/are } \\
\text { your problems } \\
\text { when you } \\
\text { complete the } \\
\text { scrapbook? }\end{array}$ & $\begin{array}{l}\text { Difficult } \\
\text { to find } \\
\text { picture }\end{array}$ & $\begin{array}{l}\text { Difficult } \\
\text { to find } \\
\text { picture } \\
\mathrm{s} \text {, have } \\
\text { to cut } \\
\text { them } \\
\text { from } \\
\text { textboo } \\
\text { ks }\end{array}$ & $\begin{array}{l}\text { Difficult } \\
\text { to find } \\
\text { picture }\end{array}$ & $\begin{array}{l}\text { Ugly } \\
\text { handwr } \\
\text { iting }\end{array}$ & $\begin{array}{l}\text { Uncrea- } \\
\text { tivite, } \\
\text { Difficult } \\
\text { to find } \\
\text { picture, } \\
\text { bad } \\
\text { handwri } \\
\text { ting }\end{array}$ \\
\hline
\end{tabular}

Similar to the interviews, an examination on scrapbooks developed by the students showed that the students produced uninteresting, shallowed and uncreative scrapbooks for their classroom assignments. This is further explained the document analysis that conducted on the past produced scrapbook, it was found that there were many shortcomings in its production. Students had produced scrapbooks through the conventional methods. This method has resulted in many detected shortcomings such as lack of detailed information, lack of interesting pictures, not being creative, messy writing, not attracting attention and also being left behind due to not using a combination of ICT at all. This disadvantages are because of their information search and use skills are not extensive i.e. limited to the resources available around them only.

As illustrated in table 2, interviews with three classroom teachers indicated that students' scrapbooks were uninteresting, which most likely due to students' inability to search and use appropriate pictures and fonts. The teachers also confirmed that not all students complete their history scrapbook, while those completed the scrapbook did not provide a satisfactory work. 
TABLE 2: SUMMARY OF TEACHERS' INTERVIEWS

\begin{tabular}{|l|c|c|c|}
\hline The questions / Answer & Teacher 1 & Teacher 2 & Teacher 3 \\
\hline $\begin{array}{l}\text { 1. Are all your students } \\
\text { completing History } \\
\text { scrapbooks? }\end{array}$ & No & No & No \\
\hline $\begin{array}{l}\text { 2. Are you satisfied with } \\
\text { the production of the } \\
\text { scrapbook? }\end{array}$ & No & No & No \\
\hline $\begin{array}{l}\text { 3. What are your } \\
\text { evaluations on their } \\
\text { works? }\end{array}$ & $\begin{array}{c}\text { Less } \\
\text { untidy, } \\
\text { awful } \\
\text { handwriting }\end{array}$ & $\begin{array}{c}\text { No } \\
\text { creativity, } \\
\text { mostly } \\
\text { messy, } \\
\text { untidy }\end{array}$ & $\begin{array}{c}\text { Less pictures } \\
\text { used, mostly } \\
\text { black and } \\
\text { white, not } \\
\text { colourful }\end{array}$ \\
\hline
\end{tabular}

Following the findings, the study developed Wakelet module to help students to find and use information in multiple formats from various sources in completing their scrapbooks. The module's learning objective was to help students to create digital scrapbooks using Wakelet application. Accordingly, the module would assist students to use Wakelet features such as writing texts, inserting images and videos, as well as linking other features to Wakelet board. To help students to attain the module's learning objective, the content of the developed module was divided into two parts; i.e. Wakelet application and Wakelet usage. For easy to access and use, the module was developed using Microsoft Office software and hand out to a students as a booklet. It is expected that after the module was implemented, students were able to use features available in Wakelet application and able to search and use various formats of online information from multiple sources available in internet to develop interesting, insighful and colourful online scrapbooks for their classroom assignments.

The study also developed learning activities, tasks and assessment to support students' learning. The learning activities that take place are students will use the Wakelet application and use all available features such as text, images, links to videos, link to twitter, bookmarks and so on. In addition, the information search techniques taught are extensive from a variety of search sources. Next, students are able to use the information to produce a Wakelet scrapbook which consists of titles, learning contents, various types of pictures and videos, questions and notes, chat rooms with teachers and friends and links to other social sites. This activity proves the application of cognitive learning when students have the opportunity to repeat the information they have learned into the form of behavior and material produced. In the final phase, the researcher will make an assessment of the comparison between the pre -test scores and the post -test scores that have been answered by the students. The researcher will also analyze the findings from the results of the document analysis checklist on past student scrapbook and the results of the most recent student scrapbook.

Data from structured interviews with five expert teachers showed content of the module are suitable and appropriate to help students to use features available in Wakelet. The expert teachers said that the instructions and explanation on how to use the Wakelet features were clear and detail.

Similarly, all expert teachers perceived that learning activities developed by the study would help students to attain the learning objectives. There were two materials provided by the researcher i.e; Wakelet application and Wakelet usage module. These two materials are the 
main content in the workshop to help students to achieve the desired objectives of the study. For evaluation of those two materials used as a learning activity, all five expert teachers stated that the study material used was appropriate and able to help students produce effective learning materials such as a digital scrapbook. The second expert teachers stated that the instructions given were very clear because the guidelines given to the students were detailed. The third expert teachers agreed that the application used was very helpful in the learning activity process because the application was better than the Pinterest application. In addition, the module used was also accurate because it explained in detail to make it easier for students to understand the method of using Wakelet application.

Expert teachers also viewed that learning tasks and assessment prepared by the study to assess students' attainment of the learning objectives were sufficient. All five expert teachers agreed with the planned learning tasks. The first expert teachers stated that the planned learning tasks were very suitable to achieve the objectives of the study. The second expert teachers stated that the planned learning tasks had continuity and able to attract students to utilize ICT in learning activities. In the meantime, all expert teachers expressed agreement with the research assessment provided. The first expert teachers stated that the research tools provided were very suitable for studying the effectiveness of the workshop. The second respondent stated that the research assessment provided were very detailed, the questions and checklists constructed were able to obtain accurate findings before and after the usage of the module. While the third expert teachers thought that the research assessment used was a clear explanation, a brief explanatory with image and could be applied by students easily. As a conclusion, all expert teachers stated that the pre -test provided could see the extent to which students to get exposure to the Wakelet application and their level of mastery and interest in online learning applications. In addition, the checklist form on the student's scrapbook before the workshop, all expert teachers thought that it helped the researcher to make a comparison. Lastly, assessment for the post-test, all expert teachers thought it could help researchers to evaluate the effectiveness of the program based on information from programme participants, and the checklist form on the digital scrapbook produced using the Wakelet application greatly helped the researcher to evaluate the effectiveness of the expected research objectives whether achieved or not.

\section{Finding of Research}

\section{Findings of Workshop Content Evaluation}

Question 1 is related to the content and the materials used during the workshop. Two materials provided by the researcher are Wakelet application and Wakelet Usage Module. These two materials are the main content in the workshop to help students to achieve the desired objectives of the study.

Based on five respondents who answered this question, they stated that the research materials used are appropriate and able to help students to produce an effective learning material such as a digital scrapbook. The instructions given are very clear because the guidance given to students is detailed and the learning application used (Wakelet) is very helpful in the learning process.

\section{Findings of Teaching Measure Evaluation}

Question 2 is related to the views on the teaching measures that have been planned to be used in the workshop. All five respondents/evaluators agreed with the planned teaching measures such as the planned teaching measures are very suitable to achieve the objectives 
of the study, have continuity and able to attract students to utilize information technology tools in T\&F session, as well as utilizing Wakelet application which has multiple functions of documenting information.

\section{Findings of Research Tools Evaluation}

Question 3 is to evaluate the research tools used whether successful or not to achieve the research objectives. In order to gain data before the implementation of the workshop, researcher has prepared two forms of research tools consisting of pre-tests and checklist forms on students' previous results. Meanwhile, to obtain data after the workshop implementation, two research tools are also provided, namely post-test and a checklist form on students' in-workshop. The first evaluator stated that the research tools provided are very suitable to study the effectiveness of the workshop. The second respondent stated that the research tools provided are very detailed. The questions and checklists constructed are able to obtain accurate findings before and after the workshop. While the third evaluator thinks that the research tools used are able to provide an explanation of the use of Wakelet which has a brief explanatory slide. There is also an image that shows the actual Wakelet display and can be applied by students easily.

\section{Teaching Measure}

The teaching measures that have been planned to be used in the workshop have received good feedbacks from the evaluators. All five respondents/evaluators stated that they agreed with the teaching measures that had been planned because they were seen to be able to achieve the objectives of the study.

\section{Research Tools}

The research tools provided by the researcher consist of pre and post workshop research tools. Analysis for pre-test and post-test was conducted by comparing student scores for the two tests to show that there is an improvement in performance after the teaching session by using the new method. The evaluators thought that the research tools provided are very suitable to study the effectiveness of the workshop. The research tools provided are also very detailed and able to obtain accurate findings related to data before and after the workshop as well as a brief explanation module and can be applied by students easily.

The evaluators also think that the constructed research tools are able to help the researcher to make a comparison between the two results of the students' presentation which are the scrapbooks produced by conventional method to the scrapbook produced by digital method. Furthermore, for the post-test, the evaluators give an opinion that it can help the researcher to evaluate the effectiveness of the program based on data from workshop participants. The rest is the checklist form on the digital scrapbook produced by using Wakelet application has greatly helped the researcher to evaluate the effectiveness of the expected research objectives whether it is achieved or not.

\section{Discussion}

Based on the findings obtained from five evaluators, the workshop is seen to have a positive impact on students. The learning activities developed by the study would help students to attain the learning objectives. Two materials provided by the researcher i.e; Wakelet application and Wakelet usage module in the workshop could help students to achieve the desired objectives of the study. Besides, the study material used was relevant, appropriate 
and able to help students to produce effective learning materials such as a digital scrapbook. The instructions given in the module were very clear because the guidelines given to the students were detailed. Overall, the module, materials, contents and learning activities used were very relevant, up to date, engaging students and effective in the whole workshop process.

Online learning applications are increasingly evolving at the global and national levels that can be fully integrated at school levels. The study suggested that Wakelet application can be used for various learning purposes such as sharing learning materials, collaborating with teachers and other students in creating digital portfolios, storybooks, newsletters, scrapbooks and other digital learning materials (Maxwell, 2018). Materials generated through Wakelet can also be linked directly to Google Classroom and Microsoft Teams. Due to these advantages, Wakelet application has been selected by the Ministry of Education in Malaysia as one of application in online learning and was made available in the portal of Digital Educational Learning Initiative Malaysia (DELIMA). Online learning applications has greatly helped teachers to manage assignments from students in a paperless learning environment by leveraging the use of Google Docs, Drive and other applications. The study showed that learning experiences in the digital age of the 21st century involving the effective use of Information ICT were able to assist students to apply cognitive, social, cultural, and technological and information skills and competencies (Forkosh-Baruch \& Avidov-Ungar, 2019). In particular, by assisting secondary school students to develop digital scrapbook using Wakelet application, the study suggested that students were able to search and use suitable and interesting information available in multiple formats from various sources.

This study suggested that teachers need to prepare themselves with ICT knowledge and skills to support students to acquire and apply information literacy in classroom learning. Moreover, ICT competencies did not only limit to ICT use, but also include with pedagogical aspects how technology is used for teaching and learning process (Becuwe et al., 2017). While Ministry of Education has provided numerous training programs to assist secondary school teachers to acquire ICT skills, the study indicated that more training programs were needed to train schoolteachers on how to use ICT to mediate teaching and learning process in the $21^{\text {st }}$ century. Moreover, the study also suggested that school management must support any teaching and learning activities mediated by ICT in term of time, human and financial resources. This suggestion is similar to Ravendran, \& Daud (2020) whose highlighted the importance of school management support for the successful implementation of ICT mediated classroom learning. However, Prasad (2015) cautioned that such support would only be realized if the school management recognize the importance of ICT application in classroom learning.

Future study could be conducted to evaluate the usability of Wakelet module from students' perspective. The study that seeks the effectiveness of the Wakelet module in improving students' information search and use could also be conducted in future study. Moreover, future study also could be conducted to investigate the use of different learning applications such as Tinkercad, Padlet, Blendspace, Plickers in helping school students to acquire and apply various components of information literacy across classroom learning.

\section{Conclusion}

This study aimed to develop and evaluate Wakelet module to assist secondary school students to search and use information in multiple formats from various sources in completing their digital scrapbook project. The study found that the developed module has a 
potential to assist students to search and use appropriate and interesting information in multiple formats from various sources in completing their digital scrapbook project. The study showed that learning process mediated by ICT was able to assist students to acquire and apply information literacy during learning process. The study suggested that programs were needed to train schoolteachers to use ICT to facilitate learning process. Moreover, the study indicated that school management awareness and support are essential for the implementation of ICTmediated classroom learning. Besides, the education department must provide more training to teachers to improve their skills in using technology.

Overall, this study proved that the development of the module has been able to provide significant changes to the level of skills in information search and use among form two students before and after the implementation of the module. The content of workshop and module, the teaching activity and the research tools were applied effectively and successfully achieved the research objectives to improve the information searching and use among lower secondary school students.

\section{References}

American Library Association. (1989). American library association presidential committee on information literacy. http://www.ala.org/ala/acrl/acrlpubs/whitepapers/presidential. htm.

American Library Association. (2000). Final Report of the American Library Association Presidential Committee on Information Literacy, 1989.

Becuwe, H., Roblin, N. P., Tondeur, J., Thys, J., Castelein, E., \& Voogt, J. (2017). Conditions for the successful implementation of teacher educator design teams for ICT integration: A Delphi study. Australasian Journal of Educational Technology, 33(2), 159-172. https://doi.org/10.14742/ajet.2789

Bundy, A. (2004). Australian and New Zealand information literacy framework. Principles, standards and practice, 2.

Coonan, E., Geekie, J., Goldstein, S., Jeskins, L., Jones, R., Macrae-Gibson, R., \& Walton, G. (2018). CILIP definition of information literacy 2018. Chartered Institute of Library and Information Professionals Information Literacy Group, 2018-04.

Eisenberg \& Berkowitz. (1987). Teaching information \& technology skills: The big 6 in elementary schools. Linworth Publishing, Inc.

Firmiana, M. E., \& Rahmawati, S. (2020). Meningkatkan keyakinan diri (self-efficacy) siswa di masa pembelajaran online selama pandemi covid-19.

Forkosh-Baruch, A., \& Avidov-Ungar, O. (2019). ICT Implementation in Colleges of Education: A Framework for Teacher Educators. Journal of Information Technology Education, 18.

Hanoum, F. C., Hermaliana, M., Aminah, S., \& Junaedi, D. (2019). Penggunaan Google Classroom Untuk Mendukung Perkuliahan Di lai-N Laa Roiba Bogor. Reslaj: Religion Education Social Laa Roiba Journal, 1(1), 21-51.

Jenkins, H. (2006). Convergence Culture. Where Old and New Media Collide. NY: New York U Press.

Kember, D., \& Gow, L. (1992). Action research as a form of staff development in higher education. Higher Education, 23(3), 297-310.

Kemmis, S., \& McTaggart, R. (1988). The action research planner. Victoria: Deakin University. Landøy, A., Popa, D., \& Repanovici, A. (2020). Basic concepts in information literacy. In Collaboration in designing a pedagogical approach in information literacy (pp. 23-38). Springer, Cham. 


\section{DEVELOPMENT}

Vol. 11, No. 1, 2022, E-ISSN: 2226-6348 @ 2022 HRMARS

Lewin, K. (1946). Action research and minority problems. Journal of social issues, 2(4), 34-46. Maxwell, L. (2018). Wakelet. The School Librarian, 66(4), 218.

McNiff, J. (1988): Action research: Principies and practice, London:Routledge.

Moosavi, Z. H., DeWitt, D., \& Naimie, Z. (2018). EFL undergraduate learners' readiness towards mobile learning. Proceeding of the 4th International Conference on Education,4(2), 121-128. Students to the Using of Virtual Learning Environment VLE Frog in Malay Language Learning). Jurnal Pendidikan Bahasa Melayu, 8(2), 53-62.

Murugan, A., Sai, G. T. B., \& Lin, A. L. W. (2017). Technological Readiness of UiTM Students in Using Mobile Phones in the English Language Classroom. Malaysian Online Journal of Educational Technology, 5(2), 51-67.

Shorfuzzaman, M., \& Alhussein, M. (2016). Modeling learners' readiness to adopt mobile learning: A perspective from a GCC higher education institution. Mobile Information Systems, 1(1), 1-10.

Omar, I. I. (2005). Panduan mencari maklumat. PTS Professional.

Prasad, C. V., Lalitha, P., \& Srikar, P. V. N. (2015). Barriers to the use of Information and Communication Technology (ICT) in secondary schools: Teacher's Perspective. Journal of Management Research, 7(2), 190.

Ravendran, D. R., \& Daud, M. Y. (2020). Faktor-faktor yang mempengaruhi guru Matematik sekolah rendah dalam mengintegrasikan penggunaan teknologi dalam PdPc. Jurnal Dunia Pendidikan, 1(3), 24-33.

Wijetunge, P., \& Alahakoon, U. P. (2005). Empowering 8: the information literacy model developed in Sri Lanka to underpin changing education paradigms of Sri Lanka. Sri Lanka Journal of Librarianship \& Information Management, Vol. 1: 31-41. 